\title{
Gender, Sex and Sexuality Grand Challenge
}

\author{
Kath Woodward* \\ Open University, Milton Keynes, UK \\ Keywords: gender studies, sexuality, interdisciplinary studies, big data, inequalities
}

Sex, gender, and sexuality have increasingly become the focus of academic research, within different disciplines as well as contributing to interdisciplinary, multidisciplinary, and transdisciplinary studies. Gender and sexuality studies are identifiable expanding, interdisciplinary fields (Richardson and Robinson, 2015). This is a multifaceted area of research, which has increasingly become recognized as important and as one which can generate new ways of thinking, which challenge traditional certainties and offer new avenues of exploration and new approaches to understanding social relations and transformations as well as addressing the dynamics of contemporary global politics and unequal power geometries. This fast moving field also presents challenges, not least of how to retain an identity and some shared purpose in changing times, when different axes of power compete for attention. Embodiment and the flesh have always been central, if troubling, to gender studies (Howson, 2005), but bodies are very different and are marked by very different sources of power (Woodward, 2009).

Sexual politics are often a key motor of activism and change and link theoretical and methodological concerns with praxis and politics, which impinge upon and arise from the personal and often intimate relationships in everyday life (Bates, 2014). This is also a highly contentious field underpinned by debate and disputation, not least through claims that second wave feminism assumed a homogeneous category "woman," which did not accommodate or acknowledge the heterogeneity of women's lives and situations, for example, in relation to class, race, ethnicity, generation, and disability (Yuval-Davis, 2006; Alexander et al., 2014). The challenge is to develop interconnections that retain the integrity and identity of disciplinarity while crossing boundaries and forging new conceptualizations and to avoid the limitations of narrowly defined internal disputes. How do we hold onto the political promise and creative capacities of analyses based upon sex, gender, and sexuality, and incorporate critiques of social inequalities and relations, which are based upon diverse social political and cultural divisions and connections.

\section{LEGACIES AND HISTORIES}

Gender and sexuality studies are distinctive in their engagement with the personal and the political, with the routine practices of daily life and the meta level of global economic systems and international and national governance and policies, which have developed though a synergy between thought and activism. These fields of research, which have emerged from the identity politics of the 1980s and 1990s (Woodward, 1997), draw upon the traditions of women's and subsequently gender studies. Gender awareness has become integral to disciplinary fields as diverse as the arts, computer sciences, humanities, science, technology and engineering, mathematics, and social sciences, as well as being distinct fields of study in their own right. Sexual politics and gender studies engage with some of the dilemmas, which have been presented by diversity policies, not least the matter of equality and difference. How is the goal of equality best achieved? Is it through different or equal treatment? Does the claim that battles have been won in sexual politics have any purchase in any arena of social, economic, or political life? European Union equality policies might be seen to have gone beyond gender or have marginalized sex (Agustin, 2013). 
The challenge is first to explore the actualities of lived experience of inequality and second to engage with the policy implications of sexual politics and to proceed in productive ways, which resist being constrained by the bureaucratic conformity, associated with some of the policies and practices of social inclusion.

Analyses which embrace sexual politics entail dismantling discipline categories in order to undertake research and combat oppression (Klein, 1995), but the promise of crossing discipline boundaries might mean subverting the basis of one's discipline, or does it mean adding on sex gender and sexuality, rather than integrating such research? I use sex gender, without a comma in order to highlight the interconnections between the two. It is not simply a matter of sex being biological and anatomical and gender being social and cultural; gender shapes sex as well as sex shapes gender. Explaining the interrelationship is another challenge, which crosses disciplines (Woodward, 2012). Interdisciplinarity can mean thinking more creatively and generating different ways of explaining and of acting upon the social relations, differences, and inequalities, which include sex, gender, and sexuality. Interdisciplinary gender and sexuality studies constitute a broad church (Richardson and Robinson, 2015).

\section{SEX, GENDER, AND SEXUALITY}

Gender studies involve a focus on the sexed body and the interrelationship between sex and gender, which at times are inextricably entangled. The term gender tends to be preferred, partly because of its wider scope and remit than the more biological, anatomical sex, and in order to challenge the apparent limitations of biological reductionism (Moi, 1999). Gender includes men and masculinities (Connell, 1995/2005, 2014). Gender is not just about women, as has so often been the case in the promotion of policies of equal opportunities in neo-liberal democracies in recent times. Men are gendered too, and the interrogation of hegemonic masculinity (Connell, 1995/2005) raises challenges to power structures in a vast range of social, economic, cultural, and political systems.

Earlier accounts suggested a division between sex as anatomical and biological and gender as the social and cultural manifestations of sex (Oakley, 1972), but what is classified as sex to is shaped by cultural forces and made through social practices. One of Judith Butler's major contributions to gender studies to the study of social relations and the operation of power across disciplines is her critique of sex and sexuality as well as gender as performativity. Sex, as much as gender, is produced by the processes and practices through which it is defined and classified. Butler's work has generated questions and debates about the materiality of sex, the fluidity, and the transgressive properties of sex, gender, and sexuality and opens up the possibility and promise of queering the debate through a celebration of transgression and a subversion of dichotomies including that of sex/gender (Butler, 1990, 1993). Similarly, recent debates about Trans (Martinez-San Miguel and Tobias, 2016) present opportunities as well as difficulties, for example, in subverting long-held certainties and cultural values about what matters. While there is increasing acceptance, at least in some parts of the world, about the right to adopt the sexual orientation which feels appropriate and possibly natural, the freedom to identify with either sex is more troubling in that sex is embedded in systems of governance; it is usually the second box you have to fill in on official forms after your name. For example, sporting bodies, such as the International Olympic Committee, have had to develop strategies for dealing with Trans and intersex athletes, who are not permitted simply to selfidentify their sex; sex is not a private matter (Woodward, 2009, 2012). Studies of gender verification testing in sport demonstrate the complicated and often futile attempts of governing bodies to establish some certainty about sex, by enlisting expertise from medical science, psychology, and anthropology in pursuit of scientific, incontrovertible truth about sex (Woodward, 2009). Science and technology are enmeshed, for example, in Donna Haraway's work (Haraway, 1997) on technoscience and Sarah Franklin's research on genetics (Franklin, 2013).

The challenge is to unpack taken for granted assumptions, to disentangle what is natural, normal, normative, and empirically observable, in order to create new ways of understanding the intersection of different power axes, which retain a focus upon structural forces and social divisions (Alexander et al., 2014).

\section{INTERSECTING SYSTEMS OF OPPRESSION}

The activism which has informed many developments in the academy in the study of sex gender and sexuality demonstrates some of the connections between different structures of oppression and the processes through which economic, social, and cultural forces intersect in different contexts. Racism, social exclusion, and class-based divisions intersect with gender and sexuality. In order to make sense of these processes, it is necessary to understand them together, rather than as separate, discrete forces, and to gather evidence of how these forces intersect. Pressing social inequalities, such as access to resources, health care, education and personal security which endure, even if they are experienced differently across the globe, where gendered inequalities persist along with economic and ethnic disadvantage (UN Violence against Women, 2015; UN Women, 2015; UN Women Reports, 2015). There is substantial statistical evidence of gender inequalities, including most pervasively the exploitation and oppression of women worldwide (Connell, 2009). However, the empirical evidence of big data demands analysis as well as description.

Another significant aspect of the analyses of big data on international social, economic, and political divisions and inequalities relates to the relationship between disciplines. Feminist critiques have developed possibilities for theorizing intersection of different power axes (Hill Collins, 1990; Crenshaw, 1991; Yuval-Davis, 2006), which have been adopted more widely to explain complex processes through which different groups of people become disenfranchised and resist oppression. Activism and resistance demonstrate diverse connections and disconnections, for example, between classes, sexes, and ethnic groups.

The challenge is to explore and understand how different power structures and systems interrelate and how they are disconnected, and to interpret and make sense of big data. 


\section{THEORIES AND PRACTICES}

Sex gender and sexuality studies and activism are marked by conflicting positions as well as some shared aims. Activism includes struggles aimed at legislative change to combat different aspects of inequality such as the UK 2010 Equality Act, which covers an ever-expanding range of sexualities as well as many sources of social exclusion, including generation, ethnicization and racialization, and human rights campaigns such as those against people trafficking and FGM. Global activism worldwide generates different positions which reflect cultural diversity, which is another of the challenges presented by this field of inquiry as well as activism in the need to be attentive to cultural relativism and very different practices across the globe.

The Internet and social media offer a new site for research because much contemporary feminist and LGBTQ campaigning, such as the signing of online petitions, websites that encourage people to relate stories of sexism (Bates, 2014) takes place online even if cyber space offers both opportunities for socially excluded groups to be heard and being the site for sexist abuse (Penny, 2014). Although the field is fast changing, it also requires conversations across generations and the exploration of endurances as well as transformations (Woodward and Woodward, 2009).

Along with the big data that highlight the scale of inequalities globally, approaches in this field have often been dominated by qualitative approaches, which highlight the lived experiences of those inequalities. Earlier feminist work, which sought to fore ground women's stories emerged in a wide range of disciplines, such as history (Rowbotham, 1975), sociology (Oakley, 1979), and anthropology (Moore, 1988, 1994), emerged as a useful strategy to highlight the ways in which women's experiences had been excluded from dominant historical and social narratives, by suggesting ways in which the stories of the disadvantaged and dispossessed could be "put into discourse" as Michel Foucault argued, happened with sexuality (Foucault, 1981: 11) and made audible and visible.

In order to address questions about how gender relations are made and re-made and how sexual politics influences experience and social, economic, and political relations, we

\section{REFERENCES}

Agustin, L. R. (2013). Gender Equality, Intersectionality and Diversity in Europe. Basingstoke: Palgrave MacMillan.

Alexander, C., Kaur, R., and St Louis, B. (2014). Mapping Changing Identities: New Direction in Uncertain Times. London: Routledge.

Bates, L. (2014). Everyday Sexism. London: Simon \& Schuster.

Butler, J. (1990). Gender Trouble: Feminism and the Subversion of Identity. New York; London: Routledge.

Butler, J. (1993). Bodies that Matter: On the Discursive Limits of Sex. London; New York: Routledge.

Connell, R. W. (1995/2005). Masculinities, 2nd Edn. Cambridge; Sydney: Polity Press; Allen and Unwin; Berkeley University of California Press.

Connell, R. W. (2009). Gender: A Short Introduction. Cambridge: Polity.

Connell, R. W. (2014). Margin becoming centre: for a world-centred rethinking of masculinities. NORMA, Int. J. Masculinity Stud. 9, 217-231. doi:10.1080/1890 2138.2014.934078 need robust empirical evidence, including statistical data as well as qualitative, ethnographic, critical discursive, and psychosocial approaches, which seek to understand some of the ambivalence and contradictory aspects of sex gender and sexuality.

\section{CHALLENGES}

Sex, gender, and sexuality are contested categories. Part of the challenge is to explore the contingent processes through which such classifications are made. Gender is both an empirical category and a theoretical conceptualization, which can help make sense of social relations and divisions as well as describing them. The challenge is to go some way toward managing both. Studying gender sex and sexuality generates different and often innovative methodologies as well as a plurality of theoretical approaches, which are directed at making sense of inequalities and at celebrating the experiences and contributions of hitherto marginalized groups (Woodward, 2014). The intimacies traditionally associated with sexuality can present methodological challenges for the researcher. This section of the journal is keen to enter into methodological conversations too.

The field is expanding and the biggest challenge is to defend the integrity of research, which combines activism with methodological and intellectual rigor while remaining open to and actively engaging with other different disciplines and with interdisciplinarity.

Frontiers offers a good place to extend the conversations and meet some of the challenges.

\section{AUTHOR NOTE}

KW is Emeritus Professor of Sociology at the Open University.

\section{AUTHOR CONTRIBUTIONS}

The author confirms being the sole contributor of this work and approved it for publication.

Crenshaw, K. W. (1991). Mapping the margins: intersectionality, identity politics and violence against women of color. Stanford Law Review 43, 1241-1299.

Foucault, M. (1981). History of Sexuality, Vol. 1. Harmondsworth: Penguin.

Franklin, S. (2013). Biological Relatives: IVF, Stem Cells, and the Future of Kinship (Experimental Futures). Durham, NC: Duke University Press.

Haraway, D. J. (1997). Modest_Witness@Second Millenium.FemaleMan_Meets_ OncoMouse: Feminism and Technoscience. New York; London: Routledge.

Hill Collins, P. (1990). Black Feminist Thought: Knowledge, Consciousness and the Politics of Empowerment. New York: Routledge.

Howson, A. (2005). Embodying Gender. London: Sage.

Klein, R. D. (1991). Passion and politics. Women's International Forum 14, $125-134$.

Martinez-San Miguel, Y., and Tobias, S. (eds). (2016). Trans Studies: the Challenge to Hetero? Homo Normativities. New Brunswick, NJ: Rutgers University Press.

Moi, T. (1999). What is a Woman? And Other Essays. Oxford: Oxford University Press.

Moore, H. (1988). Feminism and Anthropology. Cambridge: Polity. 
Moore, H. (1994). A Passion for Difference: Essays in Anthropology. Cambridge: Polity.

Oakley, A. (1972). Sex, Gender and Society. London: Maurice Temple Smith.

Oakley, A. (1979). Women Confined: Towards a Sociology of Childbirth. London; Oxford: Wiley-Blackwell.

Penny, L. (2014). Unspeakable Things. London: Bloomsbury.

Richardson, D., and Robinson, V. (2015). Introducing Gender and Women's Studies, 4th Edn. Basingstoke: Palgrave MacMillan.

Rowbotham, S. (1975). Hidden from History: 300 Years of Women's Oppression and the Struggle Against It. Basingstoke: Palgrave MacMillan.

UN Violence against Women. (2015). Available at: http://www.unwomen.org/en/ what-we-do/ending-violence-against-women/facts-and-figures

UN Women. (2015). Available at: http://www.unwomen.org/en/how-we-work/ research-and-data/publications

UN Women Reports, S. (2015). Available at: http://unstats.un.org/unsd/ demographic/products/Worldswomen/WWreports.htm

Woodward, K. (1997). Identity and Difference. London: SAGE.

Woodward, K. (2009). Embodied Sporting Identities. Basingstoke: Palgrave MacMillan.
Woodward, K. (2012). Sex, Power and the Games. Basingstoke: Palgrave MacMillan. Woodward, K. (2014). (3rd Edition) Social Sciences: The Big Issues. London: Routledge.

Woodward, K., and Woodward, S. (2009). Why Feminism Matters. Feminism Lost and Found. Basingstoke: Palgrave MacMillan.

Yuval-Davis, N. (2006). Intersectionality and Feminist Politics. Eur. J. Womens Stud. 13, 193-209. doi:10.1177/1350506806065752

Conflict of Interest Statement: The author declares that the research was conducted in the absence of any commercial or financial relationships that could be construed as a potential conflict of interest.

Copyright $\odot 2016$ Woodward. This is an open-access article distributed under the terms of the Creative Commons Attribution License (CC BY). The use, distribution or reproduction in other forums is permitted, provided the original author(s) or licensor are credited and that the original publication in this journal is cited, in accordance with accepted academic practice. No use, distribution or reproduction is permitted which does not comply with these terms. 